UDC 628.316 .12

IVANCHENKO A.V., Doctor of Tech. Sci., professor * SAVENKOV A.S., Doctor of Tech. Sci., professor ** YELATONTSEV D.O., Candidate of Tech. Sci., senior lecturer * MAKSYMCHUK Y.O., master *

* Dniprovsk State Technical University, Kamianske

** National Technical University «Kharkiv Polytechnic Institute», Kharkiv

\title{
ADSORPTION PURIFICATION OF LIQUID WASTE FROM PHOSPHATES AND RESINOUS SUBSTANCES USING NATURAL ADSORBENT BASED ON SUNFLOWER BEADS
}

Introduction. Adsorption processing of liquid waste is effective in the whole range of concentrations of dissolved impurities. Adsorption refers to simple technological processes and, in contrast to chemical and biochemical methods, can be implemented at high flow rates of the media to be cleaned.

Along with synthetic adsorbents, which are traditionally used in these processes (activated carbon, silica gels, artificial zeolites), research and practical implementation of adsorbents from natural dispersed minerals are carried out in engineering practice [1-3]. As cheap sorbents are used products of plant origin, such as wood chips, lignin, bark $[4,5]$, cellulose [6], fruit stones, soybean meal [7], husks, chitin-containing materials. The listed vegetable wastes belong to secondary material resources that are not subject to regeneration. On the other hand, in comparison with other types of secondary raw materials, the positive thing is that their stocks are constantly renewed due to the growth and development of plants.

The use of adsorbent based on sunflower husk in the processing of urban and industrial liquid waste (wastewater) is a new direction that requires scientific justification. A modified adsorbent based on sunflower husk by treatment with sulfuric acid was created. The method of obtaining the adsorbent was developed and the technological parameters of the process were experimentally determined [8].

The oil and fat industry is a branch of vegetable oil production in Ukraine, which is a powerful agro-industrial complex that unites producers of seeds and oil and fat products [9]. The industry focuses on the production of sunflower oil and related products. In the total production of oilseeds in Ukraine, sunflower occupies more than $90 \%$, and in the structure of sown areas not less than $10 \%$. The country ranks second in the world, providing from 15 to $17 \%$ of world sunflower production [9]. Oil extraction plants and oil and fat plants of Ukraine have introduced the technology of husk burning, which causes environmental damage [10].

The amount of husk waste during industrial processing of sunflower seeds is $17-20 \%$ by weight of seeds. The following uses of sunflower husk can be identified: incineration, production of pellets/briquettes, landfill, and traditional use of husk as a feed additive in livestock and poultry [9].

Formulation of the problem. Issues related to the rational use of sunflower husks remain unresolved. Of interest are studies aimed at the use of crushed husks as a natural adsorbent for the processing of liquid municipal and industrial waste.

Studies related to the use of sunflower husk for the extraction of resinous substances from coke production wastes and the concentration of phosphorus from urban wastewater are considered promising. Sunflower husk is a porous, fibrous material with a developed inner surface [11]. Sunflower husk is a raw material for the production of sorbents, as its main part consists of cellulose, lignin, which can be easily modified to give the polysaccharide matrix sorption properties [12]. 
The authors note [13] that taking into account the peculiarities of the chemical composition of sunflower husk, namely the high content of cellulose, its sorption capacity is determined by its spatial structure and properties. The structure of cellulose fiber is characterized by the presence of ordered crystalline regions, where a strong intermolecular interaction of hydroxyl groups of cellulose molecules is manifested [13].

This work aims to create an adsorbent based on sunflower husk and study its adsorption properties concerning phosphates and resinous substances.

Experimental results. Municipal liquid waste from the left bank of Kamianske with high phosphate content and industrial effluents of coke-chemical production of PJSC «Dniprovsky KHZ», the main polluting agent of which are resinous substances, were used for experimental research.

The adsorbent based on sunflower husk was obtained according to the following method [12]. The starting material was washed with hot distilled water $\left(90^{\circ} \mathrm{C}\right)$ to remove watersoluble components, followed by a mixture of benzene and ethyl alcohol (1:1), thereby removing fat-soluble compounds, coloring pigments. The resulting material was further soaked in concentrated hydrochloric acid for 2 hours at room temperature, then treated with superheated steam at $130{ }^{\circ} \mathrm{C}$. The resulting sorbent was washed with distilled water and dried in an oven at $105^{\circ} \mathrm{C}$ to constant weight, then ground with a laboratory mill to fractions of 0.3-0.5 $\mathrm{mm}$. The content of the organic part in the husk was $91.8 \%$, mineral $-8.2 \%$. Storage mineral part of the adsorbent determined using an X-ray spectrometer «ElvaX». The qualitative composition of the mineral part of the natural adsorbent based on crushed sunflower husk is shown in tabl.1.

Table 1 - Qualitative composition of the mineral part of the natural adsorbent based on sunflower husk, \%

\begin{tabular}{|c|c|c|c|c|c|c|c|c|}
\hline Type & $\mathrm{CaO}$ & $\mathrm{SiO}_{2}$ & $\mathrm{~K}_{2} \mathrm{O}$ & $\mathrm{ZnO}$ & $\mathrm{MnO}_{2}$ & $\mathrm{CuO}$ & $\mathrm{SrO}$ & Residue \\
\hline Sunflower husk & 26.105 & 34.442 & 32.982 & 1.676 & 0.679 & 0.476 & 0.238 & 3,402 \\
\hline
\end{tabular}

The dose of adsorbent was investigated in the range of $2.5-10 \mathrm{~g} / \mathrm{dm}^{3}$. For experimental tests, the effluents of the left-bank treatment facilities of Kamianske after the secondary settling tank were used, where the initial phosphate content was $21.25 \mathrm{mg} / \mathrm{dm}^{3}$. The results of the experimental study are presented in fig. 1 .

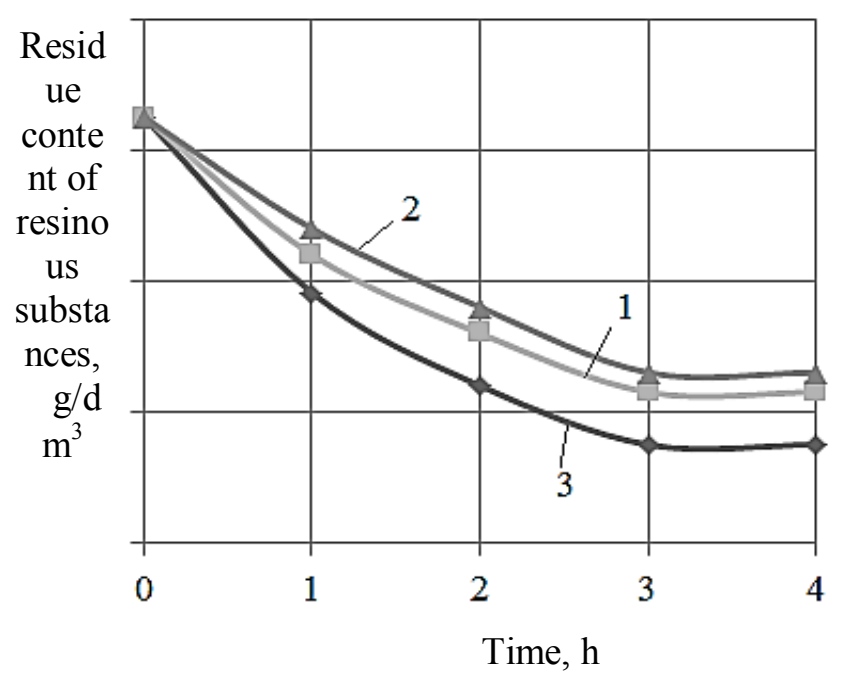

dose of adsorbent, $\mathrm{g} / \mathrm{dm}^{3}: 1-2.5 ; 2-5 ; 3-10$

Figure 1 - Dependence of the residual concentration of phosphates on the dose of adsorbent 
It is established that the greatest efficiency of removal of phosphates up to $8.75 \mathrm{mg} / \mathrm{dm}^{3}$ from municipal liquid wastes achieved by adding the adsorbent in an amount of $10 \mathrm{~g} / \mathrm{dm}^{3}$. With such technological parameters, the degree of purification reaches $59.3 \%$. It is important to note that with this method of liquid waste treatment, the $\mathrm{pH}$ value of the medium does not exceed the requirements of the quality of treated wastewater when discharged $(\mathrm{pH}=6.5-7.5)$ into natural reservoirs. The cleaning process according to the results of the research is most expedient to carry out within 3 hours. From the figure we can observe that the largest removal of phosphates occurred at a dose of adsorbent $10 \mathrm{~g} / \mathrm{dm}^{3}$, the optimal duration of the adsorption process is $3 \mathrm{~h}$. It was found that the largest extraction of phosphates occurred at a dose of adsorbent $10 \mathrm{~g} / \mathrm{dm}^{3}$, the optimal duration of the adsorption process is $3 \mathrm{~h}$.

It is assumed that the adsorption of phosphates by natural adsorbent based on sunflower husk is monomolecular in nature and is described by the Langmuir equation:

$$
A=A_{\infty} \cdot b C /(1+b C) \text {, }
$$

where $A_{\infty}$ - adsorption limit value, $\mathrm{mol} / \mathrm{g}$; $\mathrm{b}$ - the adsorption equilibrium constant.

The amount of adsorption $\mathrm{A}(\mathrm{mol} / \mathrm{g})$ is determined by the equation:

$$
A=\left(C_{0}-C\right) \cdot V / m
$$

where $V$ - the volume of solution, $\mathrm{dm}^{3} ; m$ - the mass of the adsorbent, g; $C_{0}$ - initial concentration of the extracted substance, $\mathrm{g} / \mathrm{dm}^{3} ; C$ - the residual concentration, $\mathrm{g} / \mathrm{dm}^{3}$.

According to the experimental data (table 2), the isotherm $A=f(C)$ was constructed (we assume that the isotherm is described by the Langmuir equation) and linearized.

Table 2 - Experimental data of the process of processing municipal liquid waste by natural adsorbent based sunflower husk dose $10 \mathrm{~g} / \mathrm{dm}^{3}$ and the duration of adsorption is $3 \mathrm{~h}$

\begin{tabular}{|c|c|c|}
\hline$C_{0}, \mathrm{~mol} / \mathrm{dm}^{3}$ & $C, \mathrm{~mol} / \mathrm{dm}^{3}$ & $A, \mathrm{~mol} / \mathrm{g}$ \\
\hline 0.000134 & 0.0000547 & 0.00000793 \\
\hline 0.002788 & 0.0000170 & 0.00000762 \\
\hline 0.000082 & 0.0000076 & 0.00000744 \\
\hline
\end{tabular}

The Langmuir isotherm is a straight line in $C / A$ coordinates from $C$. According to the obtained graph, the value of the limiting adsorption $A_{\infty}$ is determined, i.e. the amount of adsorbent adsorbed per unit mass (or unit area) of the adsorbent, which corresponds to the complete filling of all active centers. Phosphate adsorption isotherm from municipal liquid waste on the surface of natural adsorbent based on sunflower husk presented in fig. 2 .

The isotherm was linearized by the least-squares method. The linearized isotherm of phosphate adsorption from municipal liquid waste on the surface of a natural adsorbent based on sunflower husk is shown in fig.3.

The analysis of the linearized isotherm revealed that the adsorption limit value is:

$$
C_{\infty}=\Delta C / \Delta(C / A)=0.0000471 / 6.64=0.00000709337 \mathrm{~mol} / \mathrm{g} \text {. }
$$

The specific surface of the natural adsorbent is determined based on the sunflower husk by the equation:

$$
S_{m}=A_{\infty} \cdot N_{A} \cdot S_{0},
$$

where $N_{A}$ - Avogadro's number; $S_{0}$ - area occupied by the molecule $\mathrm{PO}_{4}{ }^{3-}, \mathrm{A}$.

The radius of the molecule $\mathrm{PO}_{4}{ }^{3-}=3.87 \mathrm{~A}$.

$$
\text { Then } S_{0}=\pi \cdot\left(3.87 \cdot 10^{-10}\right)^{2}=3.14 \cdot 60 \cdot 10^{-14}=47 \cdot 10^{-20} \mathrm{~m}^{2} \text {. }
$$




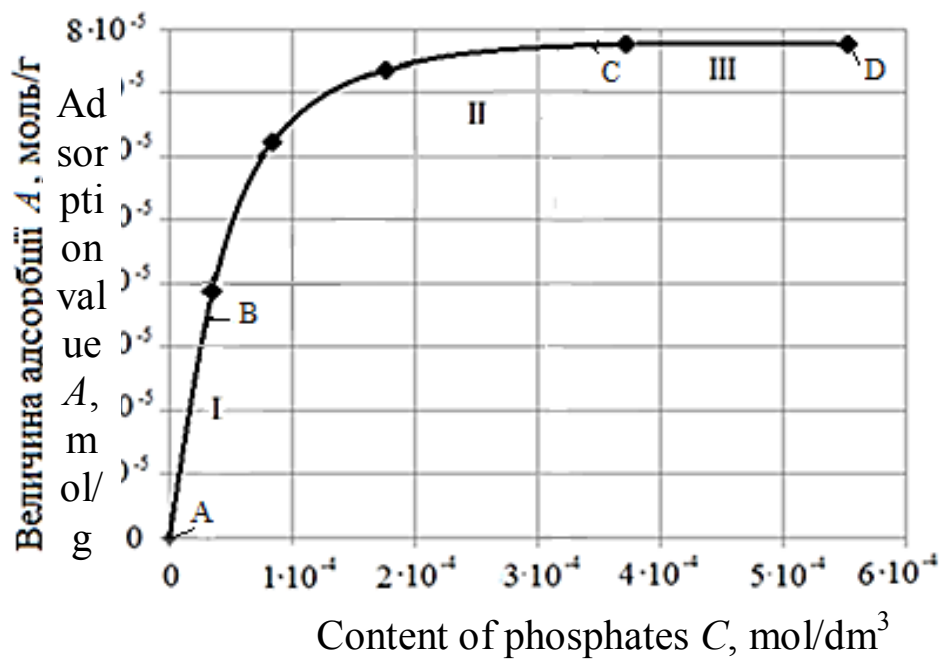

$\mathrm{AB}$ - area I; DC - area II; CD - area III

Figure 2 - Isotherm of adsorption of phosphates from municipal liquid waste on the surface of a natural sorbent based on sunflower husk

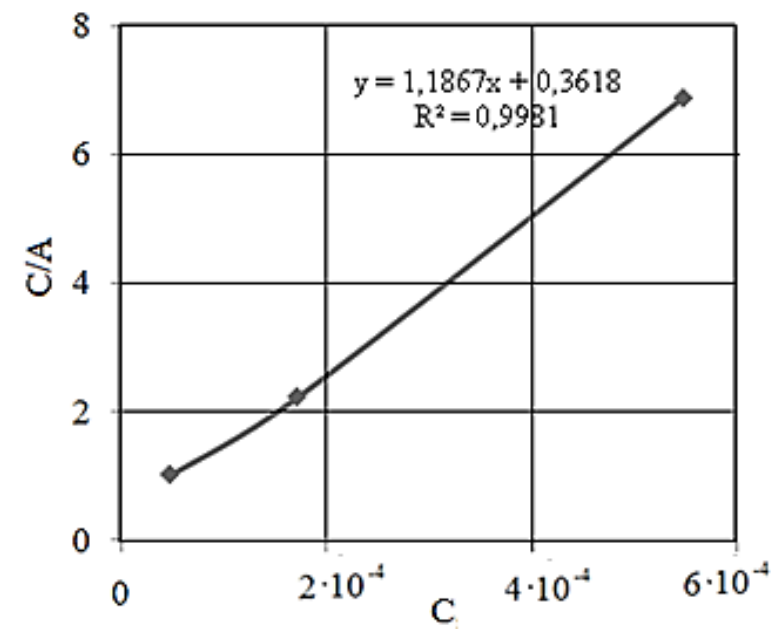

Figure 3 - Linearized isotherm of phosphate adsorption from municipal liquid waste on the surface of a natural sorbent based on sunflower husk

The specific surface area of the natural adsorbent based on sunflower husk will be:

$$
S_{m}=7.09 \cdot 10^{-6} \mathrm{~mol} / \mathrm{g} \cdot 6.022 \cdot 10^{23} \mathrm{~mol}^{-1} \cdot 47 \cdot 10^{-20} \mathrm{~m}^{2}=200.06 \mathrm{~m}^{2} / \mathrm{g} .
$$

When studying the mechanism of phosphate adsorption and the surface of the natural adsorbent based on sunflower husk, it is advisable to investigate the obtained isotherm (fig.2). It can be divided into three areas: I (AB), II (DC), III (CD).

In region $\mathrm{I}(\mathrm{AB})$, the amount of adsorption is proportional to the concentration. The experimental isotherm is a straight line starting from the origin (segment $\mathrm{AB}$, fig.2). This area can be described by Henry's law:

$$
A=k \cdot C
$$

where $k$ - Henry's constant; $C$ - phosphate concentration, $\mathrm{mol} / \mathrm{dm}^{3}$. 
In region I (segment $\mathrm{AB}$ ) of the isotherm, the surface of the adsorbent is the freest. At this point, desorption has little effect on the process. Henry's law is fulfilled only at a low degree of filling of the surface with an adsorbate. When adsorbed on solid adsorbents, the region of concentrations where Henry's law holds was small due to surface inhomogeneity. However, even on a homogeneous surface, with an increasing concentration of phosphates, Henry's law ceases to be observed. Since the concentration of the adsorbate in the volume and the surface layer of the adsorbent begins to differ and the system deviates from the ideal.

In the region of average concentrations (II, segment BC) the isotherm resembles a parabola, the dependence of the adsorption of dissolved substances on the concentration is well described by the empirical Freundlich equation:

$$
A=\beta \cdot C^{1 / n}
$$

where $\beta, n$-empirical coefficients depending on the nature of the adsorbent and temperature.

In region III (segment $\mathrm{CD}$ ), the isotherm is interpreted in a straight parallel line to the abscissa axis, with $C \rightarrow \infty, A \approx A_{\infty}$, the surface of the adsorbent is filled with adsorbate molecules. To determine the Freundlich constants $(\beta, n)$, reduce it to a linear form:

$$
\ln A=\ln \beta+1 / n \ln C .
$$

From the graph (fig.4), constructed in the coordinates $\ln A=f(\ln C$ ), we find $\operatorname{tg} \alpha=1 / n$ and $\ln \beta$, which is cut off in a straight line on the $\mathrm{y}$ axis.

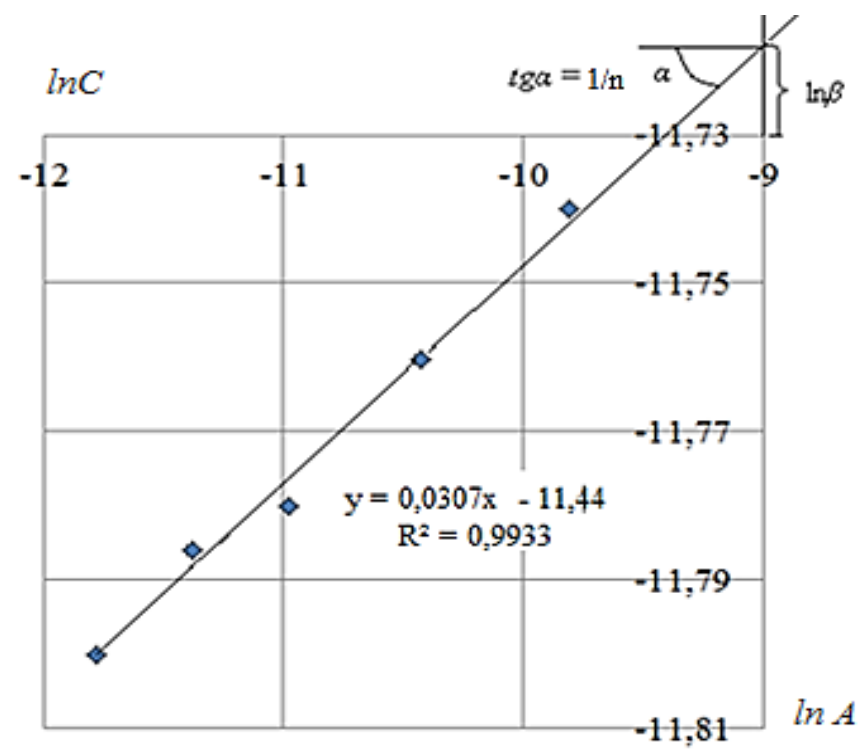

Figure 4 - Graphical definition of the constants of the Freundlich equation

The correlation coefficient of experimental and theoretical data is 0.9933 , which indicates the reliability of the results of the study.

From the graph (fig.4) determine the coefficients of the Freundlich equation:

$$
\begin{gathered}
\operatorname{tg} \alpha=1 / n=0.9325 ; \\
\ln \beta=0.025
\end{gathered}
$$

Then the Freundlich equation for the process of adsorption of phosphates from urban liquid waste on the surface of a natural adsorbent based on sunflower husk will look like:

$$
\begin{gathered}
\ln A=0.025+0.9325 \ln C ; \\
\mathrm{A}=0.025 \cdot \mathrm{C}^{0.9325} .
\end{gathered}
$$


To determine the efficiency of wastewater treatment from resinous substances, their initial and final concentration was recorded by the photometric method. The dependence of the residual concentration of resinous substances on the dose of adsorbent is shown in fig, 5 .

The equilibrium duration of sorption, which for this adsorbent was 40 minutes, and the optimal ratio of the mass of the adsorbent to the volume of wastewater $-1.5 \mathrm{~g} / \mathrm{dm}^{3}$. The adsorption process was carried out under static conditions, with constant stirring and a temperature of $323 \mathrm{~K}$. The residual concentration of the pollutant in the wastewater after treatment is 15 $\mathrm{mg} / \mathrm{dm}^{3}$, which is lower than the maximum concentration limits $\left(25 \mathrm{mg} / \mathrm{dm}^{3}\right)$.

To obtain the isotherm of adsorption of resinous substances from liquid industrial wastes of coke production on the surface of the adsorbent from sunflower husk, the effect of the sorbent dose on the residual content of resinous substances was investigated. During the experimental study, the effluents were treated with a concentration of resinous substances of $0.75,0.8,0.85$, and $0.9 \mathrm{~g} / \mathrm{dm} 3$ natural adsorbent based on sunflower husk in the amount of $1.5 \mathrm{~g} / \mathrm{dm} 3$, the duration of contact was 40 minutes (fig.6).

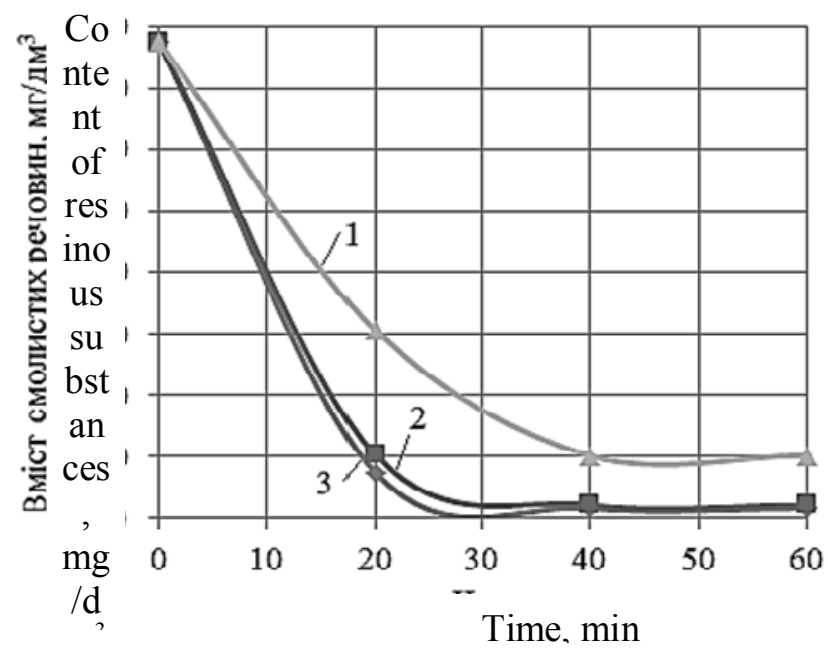

$1-1 \mathrm{~g} / \mathrm{dm}^{3} ; 2-1.5 \mathrm{~g} / \mathrm{dm}^{3} ; 3-2 \mathrm{~g} / \mathrm{dm}^{3}$

Figure 5 - Dependence of the residual concentration of resinous substances on the dose of adsorbent

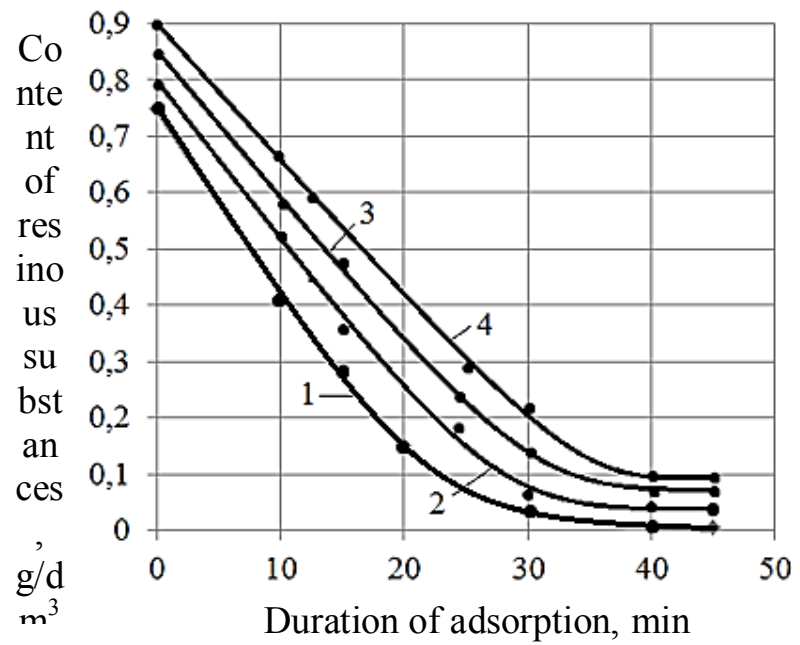

$1-0.75 \mathrm{~g} / \mathrm{dm}^{3} ; 2-0.8 \mathrm{~g} / \mathrm{dm}^{3} ; 3-0.85 \mathrm{~g} / \mathrm{dm}^{3} ; 4-0.9 \mathrm{~g} / \mathrm{dm}^{3}$

Figure 6 - Kinetic curves of the process of extraction of resinous substances from the liquid industrial waste of a coke plant depending on the initial content $\left(\mathrm{g} / \mathrm{dm}^{3}\right)$ natural adsorbent based on sunflower husk at a dose of $1.5 \mathrm{~g} / \mathrm{dm}^{3}$ 
The experimental data are listed in tabl.3 and the amount of adsorption is determined.

Table 3 - The results of an experimental study of the process of processing industrial liquid waste with a natural adsorbent based on sunflower husk dose

\begin{tabular}{|c|c|c|c|c|}
\hline$C_{0}, \mathrm{~g} / \mathrm{dm}^{3}$ & $C_{0}, \mathrm{~mol} / \mathrm{dm}^{3}$ & $C, \mathrm{~g} / \mathrm{dm}^{3}$ & $C, \mathrm{~mol} / \mathrm{dm}^{3}$ & $A, \mathrm{~mol} / \mathrm{g}$ \\
\hline 0.75 & 0.000528 & 0.006 & 0.0000423 & 0.0003238 \\
\hline 0.80 & 0.005634 & 0.045 & 0.0003160 & 0.0035453 \\
\hline 0.85 & 0.005986 & 0.078 & 0.0005490 & 0.0036246 \\
\hline 0.90 & 0.006338 & 0.010 & 0.0000704 & 0.0041780 \\
\hline
\end{tabular}

Based on experimental data, the isotherm of adsorption of resinous substances by a natural adsorbent based on sunflower husk was constructed (fig.7).

This type of isotherm indicates monomolecular adsorption, which is characteristic of microporous bodies with a relatively small proportion of the outer surface.

To determine the constants of the Freundlich equation $(\beta, n)$ a graph of the dependence of $\ln A$ on $\ln C$ is constructed (fig.8).

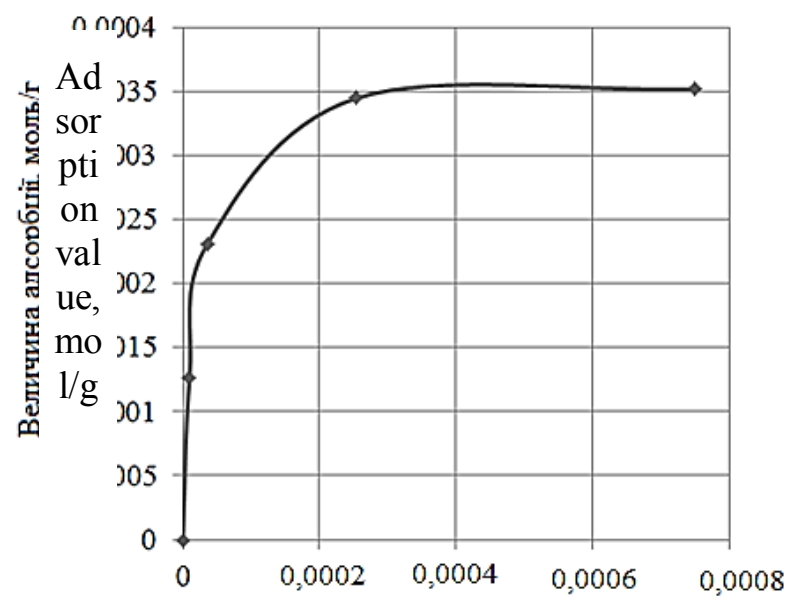

Content of resinous substances, $\mathrm{mol} / \mathrm{dm}^{3}$

Figure 7 - Isotherm of adsorption of resinous substances from liquid wastes of coke production by natural adsorbent based on sunflower husk

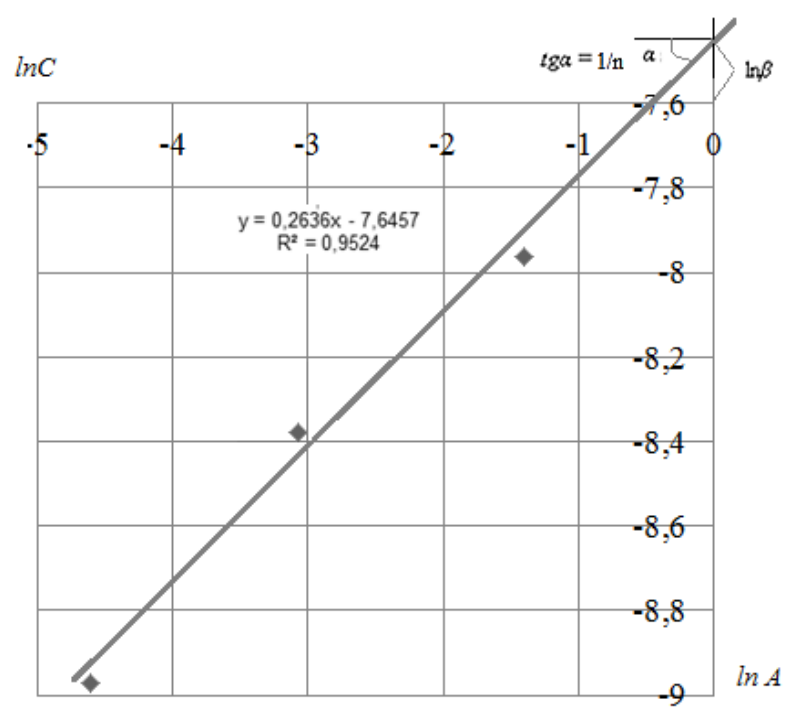

Figure 8 - Graphical definition of the constants of the Freundlich equation 
The correlation coefficient of experimental and theoretical data is 0.9793 , which indicates the reliability of experimental data.

From the graph (fig.8) the coefficients of the Freundlich equation are determined:

$$
\begin{gathered}
\operatorname{tg} \alpha=1 / n=0.7812 \\
\ln \beta=0.117
\end{gathered}
$$

Freundlich equation for the process of adsorption of resinous substances from the liquid waste of coke production by natural adsorbent based on sunflower husk will look like:

$$
\begin{gathered}
\ln A=0.117+0.7812 \ln C ; \\
A=0.117 \cdot C^{0.7812} .
\end{gathered}
$$

Conclusions and prospects for further research. It has been experimentally established that the natural adsorbent based on sunflower husk has adsorption properties. The effect of the dose of natural adsorbent based on sunflower husk, the duration of treatment on the degree of extraction of phosphates and resinous substances from wastewater was revealed. The kinetics of adsorption of pollutants were studied, the optimal parameters of adsorption purification were established, and adsorption isotherms were obtained. The theory of monomolecular adsorption (Langmuir and Freundlich equations) was used to characterize the sorbent based on sunflower husk and calculate the adsorption parameters. The specific surface area of the natural adsorbent based on sunflower husk, which is $200.06 \mathrm{~m}^{2} / \mathrm{g}$, was experimentally determined. The Freundlich equation for the processes of absorption of phosphates and resinous substances from waste is derived, which connects the concentration with the majestic adsorption. Experimental data on the degree of extraction of phosphates and resinous substances from wastewater using a natural adsorbent based on sunflower husk were obtained. In particular, after wastewater treatment with natural adsorbent, the value of the maximum concentration of resinous substances at an increased concentration of $775 \mathrm{mg} / \mathrm{dm}^{3}$ at a dose of adsorbent $1.5 \mathrm{~g} / \mathrm{dm}^{3}$ with an adsorption duration of 40 minutes; the phosphate content decreased by 2.42 times at a sorbent dose of $10 \mathrm{~g} / \mathrm{dm}^{3}$ and a purification duration of 3 hours at an initial content of $21.25 \mathrm{mg} / \mathrm{dm}^{3}$. Based on the totality of the obtained results illustrating the sorption capacity of the adsorbent, in the future. It is planned to develop resource-saving technologies for the purification of liquid waste from inorganic and organic pollutants using adsorbent based on sunflower husk and implement them in urban and industrial treatment plants.

\section{LITERATURE}

1. Манк В.В., Марцін І.І., Фіалковська Л.В. Манк В.В. Про можливість використання природних дисперсних мінералів для відбілювання соняшникової олії Хімічна промисловість Украӥни: наук.-виробн. журнал. 1997. № 4. С. 30-33.

2. Овчаренко Ф.Д. Ионный обмен и поверхностные явления на дисперсных минералах. Успехи коллоидной химии. 1973. № 3. С. 67-77.

3. Maliovany M., Gumnitsky Y., Sannikov M. Experience of using natural dispersiblis adsorbents of Ukraine for cleaning industrial drains / Mikrozanieczyszczenia w srodowisku w swietle przepisow unii europejskiej : mater. konf. Ustron. 2000. P. 90-93.

4. Далимова Г.Н., Штырлов П.Ю., Якубова М.Р. Сорбция ионов металлов техническими лигнинами и их производными. Химия природных соединений. 1998. № 3. C. 362-363.

5. Беляев Е.Ю., Беляева Л.Е. Применение целлюлозы в решении экологических проблем. Химия в интересах устойчивого развития. 2000. № 8. С. 755-761. 
6. Беляев Е.Ю., Беляева Л.Е. Использование растительного сырья в решении проблем защиты окружающей среды. Химия в интересах устойчивого развития. 2000. №8. С. 763-772.

7. Никифорова Т.Е., Козлов В.А. Сорбция ионов Сu (II) соевым шротом, модифицированным монохлацетатом натрия. Журнал прикладной химии. 2008. Т. 81. № 2. C. $428-433$.

8. Бездєнєжних Л.А. Технологія очистки соняшникової олії з використанням модифікованого адсорбенту на основі соняшникового лушпиння: автореф. дис. канд. наук: 05.18.06. 2005. 22 с.

9. Дахновська О.В. Шляхи використання соняшникового лушпиння. Збірник наукових праџьь Вінницького національного аграрного університету. 2012. т. 2 (66). №11. C.156-160.

10. Желєзна Т.К., Морозова О.С. Лушпиння соняшнику для теплових потреб. Зелена енергетика. 2007. № 4. С. 24-25.

11. Гармаш С.М. Біоконверсія рослинних відходів агропромислового комплексу та агроекологічна оцінка застосування біодобрив у північному Степу України : дис. ... канд. с.-г. наук : 03.00.16 / Український держ. хіміко-технологічний ун-т. Донецьк, 2006. $172 \mathrm{c}$.

12. Громыко Н.В. Применение подсолнечной лузги в качестве сорбента для очистки природных вод от ионов тяжелых металлов. Инновационная Наука. 2016. № 1. С. 41-42.

13. Щербаков В.Г., Ксандогиуло С.Ю., Александрова А.В. Сорбционные свойства плодовой оболочки современного подсолнечника к растительному маслу и другим неполярным органическим жидкостям. Известия Вузов. Пищевая технология. 2003. № 5-6. С. 27-28. 